\title{
Humus accumulation and microbial activities in calcari-epigleyic fluvisols under grassland and forest diked in for 30 years
}

\author{
Oliver Dilly*, Anja Gnaß, Eva-Maria Pfeiffer \\ Institut für Bodenkunde, Universität Hamburg, Allende-Platz 2, 20146 Hamburg, Germany
}

Received 6 December 2004; received in revised form 2 March 2005; accepted 24 March 2005

\begin{abstract}
The accumulation and transformation of organic matter during soil development is rarely investigated although such processes are relevant when discussing about carbon sequestration in soil. Here, we investigated soils under grassland and forest close to the North Sea that began its genesis under terrestrial conditions 30 years ago after dikes were closed. Organic C contents of up to $99 \mathrm{mg} \mathrm{g}^{-1}$ soil were found until $6 \mathrm{~cm}$ soil depth. The humus consisted mainly of the fraction lighter than $1.6 \mathrm{~g} \mathrm{~cm}^{-3}$ which refers to poorly degraded organic carbon. High microbial respiratory activity was determined with values between 1.57 and $1.17 \mu \mathrm{g} \mathrm{CO}_{2}-\mathrm{C} \mathrm{g}^{-1}$ soil h ${ }^{-1}$ at $22{ }^{\circ} \mathrm{C}$ and 40 to $70 \%$ waterholding capacity for the grassland and forest topsoils, respectively. The microbial $\mathrm{C}$ to organic $\mathrm{C}$ ratio showed values up to $20 \mathrm{mg} \mathrm{C}_{\text {mic }} \mathrm{g}^{-1}$ $\mathrm{C}_{\text {org }}$. Although up to $2.69 \mathrm{~kg} \mathrm{C} \mathrm{m}^{-2}$ were estimated to be sequestered during 30 years, the microbial indicators showed intensive colonisation and high transformation rates under both forest and grassland which were higher than those determined in agricultural and forest topsoils in Northern Germany.
\end{abstract}

(C) 2005 Elsevier Ltd. All rights reserved.

Keywords: Carbon sequestration; Organic carbon; Microbial biomass; Microbial respiration; Reclamation; Soil development

Carbon sequestration in soil became great attention since soil represents a great organic carbon pool of $1500-2000 \mathrm{Gt}$ in comparison to $450-650 \mathrm{Gt}$ stored in the vegetation and $730 \mathrm{Gt}$ in the atmosphere (German Advisor Council on Global Change, 2003). Beside carbon sequestered by the vegetation and stored in Histosols, agricultural management practices and particularly the tillage system may contribute to global soil organic C dynamics (Lal et al., 2004).

A key component when analysing carbon sequestration is soil respiration under field conditions. The magnitude of soil carbon liberation by respiratory processes is assumed to be 10-fold higher than human fossil fuel combustion and 2.5-fold higher than litter deposition to soil (Andrews and Schlesinger, 2001). Small modification of climate conditions may switch soil balance from $\mathrm{C}$ source to $\mathrm{C}$ sink or vice versa.

Beside soil respiration estimated in the field, microbial basal respiration under laboratory conditions is considered

\footnotetext{
* Corresponding author.

E-mail address: o.dilly@ifb.uni-hamburg.de (O. Dilly).
}

0038-0717/\$ - see front matter (C) 2005 Elsevier Ltd. All rights reserved. doi:10.1016/j.soilbio.2005.03.014 as an indicator for soil quality referring to both current microbial physiology and C mineralization intensity (Dilly, 2005). In addition, substrate-induced respiration refers to microbial biomass content (Anderson and Domsch, 1978) and the combination of both characterise ecosystem development (Wardle and Ghani, 1995).

Based on $\mathrm{C}$ pools and microbiological indicators, the aim of this study was to quantify the content and composition of accumulated humus and also to evaluate the microbial activity in young soils close to the North Sea.

In 1973, the influence of the North Sea was eliminated at the 'Katinger Watt' by closing the dike and belongs to a natural reserve. The reclaimed site has a long-term mean annual temperature of $7.9^{\circ} \mathrm{C}$ with an annual rainfall of approximately $800 \mathrm{~mm}$. Grassland containing mainly Festuca at the sampling period was at one part, forest stands with Populus, Alnus, Quercus, Fraxinus and Acer ssp. were afforested at another part (Fig. 1). The forest on marshland soils represents an unusual land-use system.

Two guiding sites below grassland and forest were selected from which basic soil properties were determined (Grassland $54^{\circ} 16,75^{\prime} \mathrm{N} ; 8^{\circ} 52,29^{\prime} \mathrm{E}$; Quercus forest $54^{\circ}$ $16,40^{\prime} \mathrm{N} ; 8^{\circ} 52,21^{\prime} \mathrm{E}$ ). During the 30 years, the grassland was lightly grazed by sheep during summer and autumn or cut in 


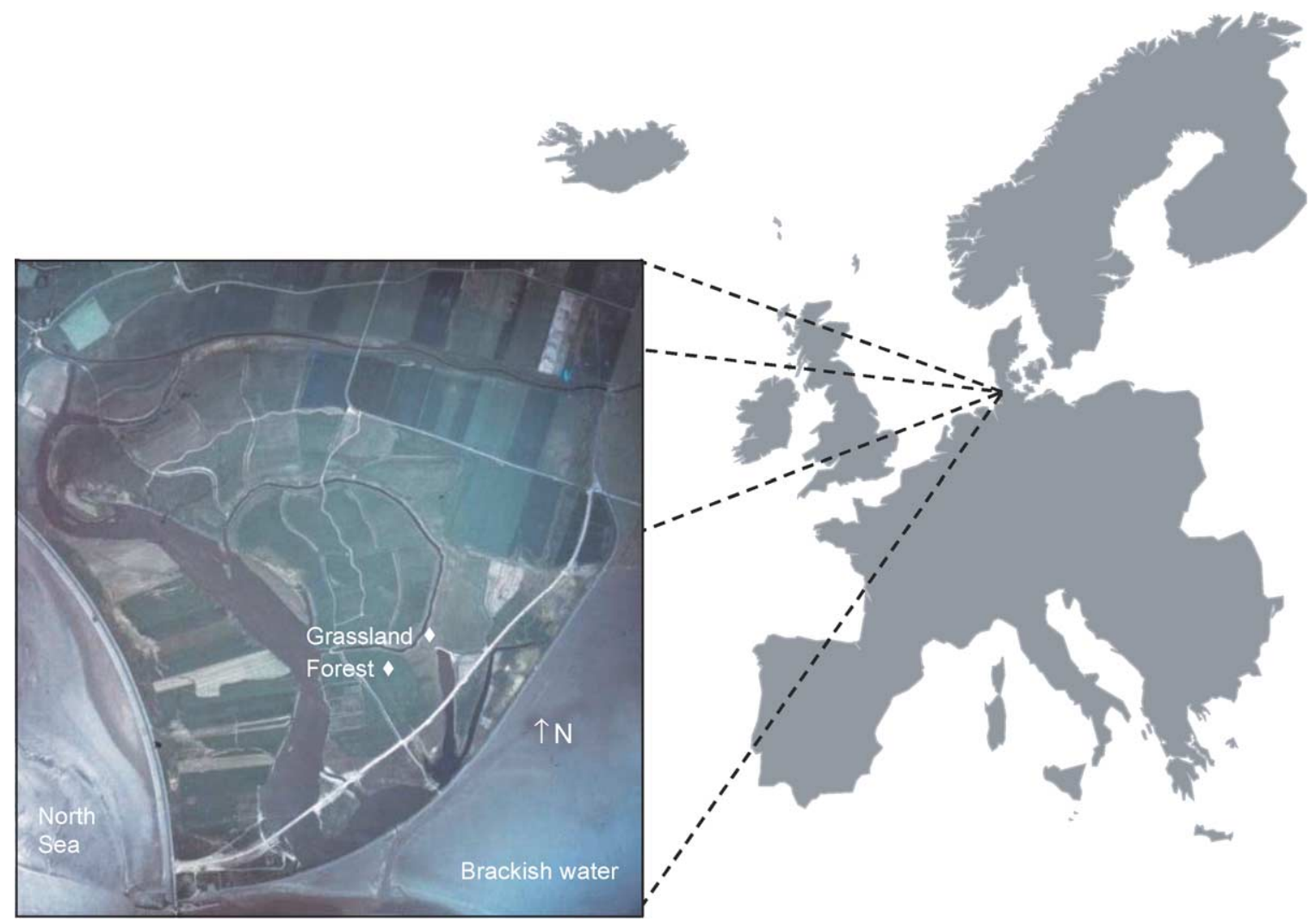

Fig. 1. Aerial view with the guiding sites of the grassland and Quercus forest at the Katinger Watt in Schleswig-Holstein, Northern Germany.

the late summer (during the last 6 years). The soil types were classified as Calcari-Epigleyic Fluvisols with calcium carbonate and reducing conditions within $50 \mathrm{~cm}$ of the soil surface (WRB, 1998). Soil texture varied with approximately $6 \%$ clay, $17-27 \%$ silt and $66-78 \%$ sand. In addition to the sampling at the guiding profiles, multiple soil cores were taken at four locations at the forest and grassland, respectively. After removal of living plant residue, soil was sieved at 2-mm mesh size. Material was dried for elementary analysis and stored fresh at $4{ }^{\circ} \mathrm{C}$ for microbial investigations not longer than 1 month. Humus chemistry with dry soil was done using density fractionation after Beudert (1988) using sodium polywolframate $\left(\mathrm{Na}_{6}\left(\mathrm{H}_{2} \mathrm{~W}_{12}\right.\right.$ $\left.\mathrm{O}_{40}\right) \cdot \mathrm{H}_{2} \mathrm{O} ; \mathrm{Fa}$. SOMETU, Berlin). Microbial respiratory activity was quantified with a Sapromat respirometer as described in detail by Dilly (2001). Since soil $\mathrm{pH}\left(\mathrm{H}_{2} \mathrm{O}\right)$ value ranged between 6.2 and 7.0 in the topsoils and from 6.7 to 7.8 in the subsoils, soil was preconditioned in the Sapromat in the presence of sodium hydroxide for 3 days to absorb abiotic $\mathrm{CO}_{2}$. Thereafter basal respiration was determined for about $24 \mathrm{~h}$, the alkali trap was exchanged and glucose added at the rate of $12.5 \mathrm{mg}$ per $\mathrm{g}$ of topsoil and $5 \mathrm{mg}$ for the subsoil to induce maximal initial respiratory response (MIRR). Substrate-induced respiration was measured for $4 \mathrm{~h}$. Carbon dioxide values were used here.

Between 36 and $99 \mathrm{mg}$ organic $\mathrm{C} \mathrm{g}^{-1}$ soil were present in the A horizons after 30 years (Table 1). The A horizons had a thickness between 5-6 cm. The $\mathrm{C}_{\text {org }}$ content in the $\mathrm{B}$ horizon ranged between 2 and $4 \mathrm{mg}$ organic $\mathrm{C} \mathrm{g}^{-1}$ soil. In accordance, an average value of $2.4 \mathrm{mg}$ organic $\mathrm{C} \mathrm{g}^{-1}$ was recorded by Joergensen and Mueller (1995) for tidal flat sediments close to the nearby island Sylt. Thus, values in

Table 1

Abiotic characteristics of marshland soils under grassland and Quercus forest at the Katinger Watt in Schleswig-Holstein, Northern Germany

\begin{tabular}{llllllllll}
\hline Site & Horizon & $\begin{array}{l}\text { Thickness } \\
(\mathrm{cm})\end{array}$ & $\begin{array}{l}\mathrm{pH} \mathrm{value} \\
\left(\mathrm{CaCl}_{2}\right)\end{array}$ & $\begin{array}{l}\text { Bulk density } \\
\left(\mathrm{mg} \mathrm{g}^{-1}\right)\end{array}$ & $\begin{array}{l}\mathrm{C}_{\text {org }} \\
\left(\mathrm{mg} \mathrm{g}^{-1}\right)\end{array}$ & $\begin{array}{l}\text { Accumulated } \\
\mathrm{C}\left(\mathrm{kg} \mathrm{m}^{-2}\right)\end{array}$ & $<1.6(\%)$ & $1.6-2.0(\%)$ & $>2.0(\%)$ \\
\hline Grassland & $\mathrm{Ah}$ & 5 & 6.3 & 0.57 & 99 & 2.69 & 97 & 2 & 1 \\
& $\mathrm{~B}^{\mathrm{a}}$ & 10 & 7.3 & 1.50 & 4 & - & $\mathrm{ND}$ & $\mathrm{ND}$ & $\mathrm{ND}$ \\
Forest & $\mathrm{Ah}$ & 6 & 6.9 & 0.83 & 36 & 1.69 & 89 & 6 & 5 \\
& $\mathrm{~B}^{\mathrm{a}}$ & 9 & 7.5 & 1.55 & 2 & - & $\mathrm{ND}$ & $\mathrm{ND}$ & $\mathrm{ND}$ \\
\hline
\end{tabular}

Abbreviation: Not determined ND

${ }^{a}$ The B horizon is more that $30 \mathrm{~cm}$ thick but was only sampled for 9 or $10 \mathrm{~cm}$. 
Table 2

Microbial indicators of marshland soils under grassland and Quercus forest at the Katinger Watt in Schleswig-Holstein, Northern Germany

\begin{tabular}{|c|c|c|c|c|c|c|}
\hline Site & Horizon & $\begin{array}{l}\text { BAS }\left(\mu \mathrm{g} \mathrm{CO}_{2}-\mathrm{C}\right. \\
\left.\mathrm{g}^{-1} \text { soil h}^{-1}\right)\end{array}$ & $\begin{array}{l}\text { MIRR }\left(\mu \mathrm{g} \mathrm{CO}_{2}-\mathrm{C}\right. \\
\left.\mathrm{g}^{-1} \text { soil } \mathrm{h}^{-1}\right)\end{array}$ & $\begin{array}{l}q \mathrm{CO}_{2}\left(\mathrm{mg} \mathrm{CO}_{2}-\mathrm{C}\right. \\
\mathrm{g}^{-1} \mathrm{C}_{\text {mic }} \mathrm{h}^{-1}\end{array}$ & $\begin{array}{l}\mathrm{C}_{\text {mic }} \mathrm{C}_{\text {org }}^{-1} \\
\left(\mathrm{mg} \mathrm{g}^{-1}\right)\end{array}$ & $\begin{array}{l}\text { BAS C } \mathrm{C}_{\text {org }}^{-1}\left(\mu \mathrm{CO}_{2}-\mathrm{C}\right. \\
\left.\mathrm{g}^{-1} \mathrm{C}_{\text {org }} \mathrm{h}^{-1}\right)\end{array}$ \\
\hline \multirow[t]{2}{*}{ Grassland } & $\mathrm{Ah}$ & $1.57 \pm 0.39$ & $16.16 \pm 6.06$ & $1.53 \pm 0.25$ & 13 & 16 \\
\hline & B & $0.19 \pm 0.02$ & $0.53 \pm 0.10$ & $4.46 \pm 1.43$ & 11 & 51 \\
\hline \multirow[t]{2}{*}{ Forest } & $\mathrm{Ah}$ & $1.17 \pm 0.18$ & $9.00 \pm 1.60$ & $1.68 \pm 0.51$ & 20 & 32 \\
\hline & B & $0.17 \pm 0.05$ & $0.49 \pm 0.19$ & $3.69 \pm 2.19$ & 16 & 71 \\
\hline
\end{tabular}

Abbreviations: Basal respiration BAS. Maximal initial respiratory response MIRR; mean \pm standard deviation $(n=4)$.

the subsoil of the Katinger Watt fit to the $\mathrm{C}$ content of marine origin and were considered as background organic $\mathrm{C}$ values before terrestrial soil development.

The organic $\mathrm{C}$ content was higher under grassland than under forest. The covariance was 33 and $48 \%$ on the basis of loss on ignition estimations at 8 and 10 locations at the grassland and forest, respectively. We observed seasonally variable thickness of litter layer with values of up to $3 \mathrm{~cm}$. The litter underwent high degradation rates in this soil with high $\mathrm{pH}$ value (Table 1). Since small amounts of litter remained 1 year after its deposition on the A horizon we did not consider carbon stored above A horizon. Based on the bulk density between 0.57 and $0.83 \mathrm{~g} \mathrm{~cm}^{-3}$, the horizon thickness of 5-6 cm and the difference in the $\mathrm{C}_{\text {org }}$ content between $\mathrm{A}$ and $\mathrm{B}$ horizon, an organic $\mathrm{C}$ accumulation was 1.69 and $2.69 \mathrm{~kg} \mathrm{~m}^{-2}$ for the forest and the grassland, respectively (Table 1). This calculation suggests that $\mathrm{C}$ sequestration was higher in grassland than in forest $\mathrm{A}$ horizon with 90 vs $56 \mathrm{~g} \mathrm{C} \mathrm{m}^{-2} \mathrm{yr}^{-1}$.

The $\mathrm{C}$ sequestration over the 30 years was much higher than that reported for ecosystem types worldwide ranging between 0.2 and $11.7 \mathrm{~g} \mathrm{C} \mathrm{m}^{-2} \mathrm{yr}^{-1}$ during 1000 to 10,000 $\mathrm{yr}$ accumulation intervals (Schlesinger, 1997). However, it was lower than the $400 \mathrm{~g} \mathrm{C} \mathrm{m}^{-2} \mathrm{y}^{-1}$ modelled for newly formed marsh soils in US (Hussein et al., 2004). On a global level, our site seems to have a high $\mathrm{C}$ sequestration potential. Under agricultural land use, the $C$ sequestration in soils is more susceptible to management (Bronson et al., 2004; Lal, 2004) and particularly then the exact estimation of changes in soil organic carbon is considered as complicated (Smith, 2004).

According to the humus fractionation, material lighter than $1.6 \mathrm{~g} \mathrm{~cm}^{-3}$ is considered as poorly decomposed. This fraction was predominant with approximately $97 \%$ under grassland and $89 \%$ under forest (Table 1). Consequently, the proportion of $1.6-2$ and $>2.0 \mathrm{~g} \mathrm{~cm}^{-3}$ which refers to transformed organic compounds was higher the soil organic matter under forest. More humified organic matter in the forest topsoil reflected both higher input of resistant litter and higher degree of humification in comparison to the grassland. Moreover, the proportion of poorly decomposed humus was generally higher in the A horizon at the young sites at the Katinger Watt in comparison to forest soils with longer development (Beudert, 1988; Rovira and Vallejo, 2003).
The microbial respiration was $1.17-1.57 \mu \mathrm{g} \mathrm{CO}_{2}-\mathrm{Cg}^{-1}$ soil $\mathrm{h}^{-1}$ in the A horizon and 0.17-0.19 $\mu \mathrm{C} \mathrm{CO}_{2}-\mathrm{C} \mathrm{g}^{-1}$ soil $\mathrm{h}^{-1}$ in the $\mathrm{B}$ horizon (Table 2). The respiration rates were higher in the grassland than the forest soil and also 237 and $195 \%$ higher than those reported for grassland and beech forest A horizons in the Bornhöved Lake District, which is also located in Schleswig-Holstein (Dilly, 2001). However, the respiratory activity related to soil organic $\mathrm{C}$ content of Katinger Watt soils of $16-71 \mu \mathrm{g} \mathrm{CO}_{2}-\mathrm{C} \mathrm{g}^{-1} \mathrm{C}_{\text {org }} \mathrm{h}^{-1}$ are the same order of magnitude as determined for soils in the Bornhöved Lake district and were enhanced in the deeper horizons.

Glucose was added to soil to induce the maximal initial respiratory response period and to estimate the size of the soil microbial biomass. More organisms were stimulated in the grassland than in the forest soil. Similar to basal respiration the values were higher than those reported from the Bornhöved Lake District when biomass data are related to soil dry weight (Dilly, 2001) but range in the same order of magnitude when related to soil organic $\mathrm{C}$ content. Consequently, the metabolic quotient $\left(q \mathrm{CO}_{2}\right)$ which relates the basal respiration to microbial biomass produced similar values for the A horizon than those found in the Bornhöved Lake district. The $q \mathrm{CO}_{2}$ is discussed as an indicator for disturbance and ecosystem development (Wardle and Ghani, 1995) and also for favourable conditions like high nutrient availability in fresh litter (Dilly and Munch, 1996) In our study, the $q \mathrm{CO}_{2}$ value did overall not indicate an early stage of succession in the A horizon. The high $q \mathrm{CO}_{2}$ values in the deeper $\mathrm{B}$ horizon were attributed to low biomass values and most likely high carbon availability (Dilly and Munch, 1996) which is also reflected in higher respiratory activities related to soil organic C content. Similarly, an increase in $q \mathrm{CO}_{2}$ values was observed earlier until $100 \mathrm{~cm}$ soil depths, which was explained by low availability of highly, humified organic matter and low yield efficiency (Meyer et al., 1996).

In conclusion, more than $1.69 \mathrm{~kg}$ organic $\mathrm{C}$ per $\mathrm{m}^{2}$ was calculated to be sequestered during 30 years of soil development. Concurrently, high microbial activity and microbial biomass were built up. The results indicate that both carbon sequestration and $\mathrm{CO}_{2}$ emission are relatively high in young soils reclaimed from the sea. Further investigations will address biodiversity, spatial variability of stabile and labile $\mathrm{C}$ and $\mathrm{N}$ pools either on soil dry weight, 
on area or $\mathrm{C}_{\text {org }}$ basis and furthermore on the estimation of in-situ $\mathrm{C}$ in- and efflux.

\section{Acknowledgements}

We thank the Forstamt in Bredstedt, in particular Dr. Knierim and Mr Rabeler, for the kind cooperation. The authors are grateful for the excellent technical assistance from Anne Schlöbohm and Susanne Kopelke. This investigation was in part supported by the German Research Foundation (DFG; project no. MU 831/12-2).

\section{References}

Anderson, J.P.E., Domsch, K.-H., 1978. A physiological method for measurement of microbial biomass in soils. Soil Biology \& Biochemistry $10,215-221$.

Andrews, J.A., Schlesinger, W.H., 2001. Soil $\mathrm{CO}_{2}$ dynamics, acidification, and chemical weathering in a temperate forest with experimental $\mathrm{CO}_{2}$ enrichment. Global Biogeochemical Cycles 15, 149-162.

Beudert, G., 1988. Mikromorphologische, nasschemische und ${ }^{13} \mathrm{C}-\mathrm{NMR}$ spektroskopische Kennzeichnung der organischen Substanz von Waldhumusprofilen nach Dichtefraktionierung. Bayreuther Bodenkundliche Berichte 8, 1-133.

Bronson, K.F., Zobeck, T.M., Chua, T.T., Acosta-Martinez, V., Scott van Pelt, R., Booker, J.D., 2004. Carbon and nitrogen pools of southern high plains cropland and grassland soils. Soil Science Society American Journal 68, 1695-1704.

Dilly, O., 2001. Microbial respiratory quotient during basal metabolism and after glucose amendment in soils and litter. Soil Biology \& Biochemistry 33, 117-127.
Dilly, O., 2005. Estimating soil microbial activity. In: Bloem, J., Hopkins, D., Benedetti, A. (Eds.), Microbiological methods for assessing soil quality. CABI, Wallington (in press).

Dilly, O., Munch, J.-C., 1996. Microbial biomass content, basal respiration and enzyme activities during the course of decomposition of leaf litter in a black alder (Alnus glutinosa (L.) Gaertn.) forest. Soil Biology \& Biochemistry 28, 1073-1081.

German Advisor Council on Global Change, 2003. World in Transition. Towards sustainable energy systems. Earthscan, London.

Joergensen, R., Mueller, T., 1995. Estimation of the microbial biomass in tidal flat sediment by fumigation-extraction. Helgoländer Meeresuntersuchungen 49, 213-221.

Hussein, A.H., Rabenhorst, M.C., Tucker, M.L., 2004. Modeling of carbon sequestration in coastal marsh soils. Soil Science Society American Journal 68, 1786-1795.

Lal, R., 2004. Soil carbon sequestration impacts on global climate change and food security. Science 304, 1623-1627.

Lal, R., Griffin, M., Apt, J., Lave, L., Morgan, M.G., 2004. Managing soil carbon. Science 304, 393.

Meyer, K., Joergensen, R.G., Meyer, B., 1996. The effects of reduced tillage on microbial biomass $\mathrm{C}$ and $\mathrm{P}$ in sandy loess soils. Applied Soil Ecology 5, 71-79.

Rovira, P., Vallejo, V.R., 2003. Physical protection and biochemical quality of organic matter in Mediterranean calcareous forest soils: a density fractionation approach. Soil Biology \& Biochemistry 35, 245-261.

Schlesinger, W.H., 1997. Biogeochemistry, An analysis of global change. Academic Press, San Diego.

Smith, P., 2004. How long before a change in soil organic carbon can be detected?. Global Change Biology 11, 1878-1883.

Wardle, D.A., Ghani, A., 1995. A critique of the microbial metabolic quotient $\left(\mathrm{qCO}_{2}\right)$ as a bioindicator of disturbance and ecosystem development. Soil Biology \& Biochemistry 27, 1601-1610.

WRB, 1998. World reference base for soil resources. World Soil Resources, Report 84. FAO, Rome. 